\title{
Occupational Violence in Nursing: Explanations and Coping Strategies ${ }^{1}$
}

\author{
Angelina María Dois Castellón ${ }^{2}$
}

This study explored part of the experience of occupational harassment, experienced by thirteen Chilean nurses, analyzing the relationship between the explanations and their coping strategies, to formulate a comprehensive model that includes the involved elements and that can be used to develop preventive strategies. Data were collected through semistructured interviews, using theoretical saturation as the ending criterion and were analyzed according to the procedures of Grounded Theory. The relational analysis shows the influence of factors that perpetuate the phenomenon, both the organizational factors and the ones related to the execution of professional roles. According to the comprehensive model, this kind of violence is a circular phenomenon, in which the involved elements influence each other and are related to the narrative constructions of the phenomenon and to contextual elements, which can also be considered as part of the most probable cause of it.

Descriptors: Adaptation, Psychological; Nurses, Male; Occupational Health.

\footnotetext{
${ }^{1}$ Paper extracted from Master's Thesis "Hostigamiento laboral en enfermeras: explicaciones y estrategias de afrontamiento" presented to Facultad de Ciencias Sociales, Pontificia Universidad Católica de Chile.

2 Nurse-Midwife, M.Sc. in Health Psychology, Specialist in Family Therapy and Couples, Associate Professor, Escuela de Enfermería, Pontificia Universidad Católica de Chile. E mail: adois@uc.cl.
}

Corresponding Author:

Angelina Maria Dois Castellón

Pontificia Universidad Católica de Chile. Escuela de Enfermería.

Departamento de Salud del Adulto y Senescente

Av. Vicuña Mackena, 4860

Bairro Macul

7820436 Santiago de Chile, Chile

E-mail: adois@uc.cl 


\section{Violência laboral em enfermeiras: explicações e estratégias de enfrentamento}

O objetivo do estudo foi explorar parte da experiência do assédio laboral, vivenciado por treze enfermeiras chilenas, analisando a relação entre as explicações e as estratégias de enfrentamento, para formular um modelo compreensivo que inclua os elementos envolvidos e que possa ser utilizado para desenvolver estratégias preventivas. Os dados foram coletados através de entrevistas semiestruturadas, utilizando como critério de finalização a saturação teórica e analisados segundo os procedimentos da Grounded Theory. A análise relacional mostra a influência de fatores perpetuantes do fenômeno, também dos fatores organizacionais e dos relacionados à execução do papel profissional. A partir do modelo compreensivo se postula que esse tipo de violência é fenômeno circular, no qual os elementos envolvidos se influenciariam e se relacionariam com as construções narrativas do fenômeno e com elementos contextuais, todos podem, também, ser considerados como parte da causalidade mais provável do mesmo.

Descritores: Adaptação Psicológica; Enfermeiros; Saúde do Trabalhador.

\section{Violencia laboral en enfermeras: explicaciones y estrategias de afrontamiento}

El objetivo del estudio fue explorar parte de la experiencia de hostigamiento laboral vivida por trece enfermeras chilenas, analizando la relación entre sus explicaciones y sus estrategias de afrontamiento, para luego formular un modelo comprensivo que contenga los elementos involucrados y que pueda utilizarse para desarrollar estrategias preventivas. Los datos se recolectaron a través de entrevistas semi estructuradas utilizando como criterio de finalización la saturación teórica y se analizaron según los procedimientos de la Grounded Theory. El análisis relacional muestra la influencia de factores que perpetuán el fenómeno, tanto los organizacionales como los relativos a la ejecución del rol profesional; utilizando el modelo comprensivo se postula que este tipo de violencia es un fenómeno circular, en el cual los elementos intervinientes se influyen mutuamente relacionándose con las construcciones narrativas del fenómeno y con los elementos contextuales, los cuales también pueden considerarse como parte de la causalidad más próxima del mismo.

Descriptores: Adaptación Psicológica; Enfermeros; Salud Laboral.

\section{Introduction}

Mobbing is an occupational situation in which someone is the object of negative, intentional, persistent and repetitive actions, characterized by the asymmetry of the relationship, the relative difference of power between victim and harasser and the absence of visible sequelae, except for the psychological deterioration of the victim(1).

International evidence suggest high rates of mobbing against nurses ${ }^{(2-4)}$. Among the causes, personal and organizational characteristics are mentioned, and the apparent existence of a culture in the nursing teams that make the problem seem invisible and increase the probability of being a victim of it (1,3,5-9). $^{2}$

Among its consequences, higher rates of accidents, long medical leaves, isolation, alterations in physical and mental health, changes in social relationships and in the attention needed to execute 
the job are described(5-6,9). Some studies show that to face these situations, nurses choose strategies that range from passiveness and defenselessness to the use of support networks, and the percentage of professionals who ignore the situation or throw up work is not low ${ }^{(3,10-11)}$. In Chile, $30 \%$ of the workers report being a victim of mobbing and the organizational/occupational deficiencies are the ones most associated with the phenomenon. On the other hand, the availability of nurses meet only $51 \%$ of the country's demand, which causes a higher overload and increases the risk of violent phenomena occurring, which directly affects professionals and users, who see themselves involved as secondary victims, once nurses neglect their work activities as a consequence of the process of victimization, resulting in care with lower quality, and in some cases even negligence(4). Thus, this study explores a part of the phenomenon and analyzes the explanations regarding harassment given by nurses who were victims of it and how they are related to their coping strategies, in order to formulate a comprehensive model that accounts for the elements involved and that can be used to develop prevention strategies.

\section{Methods}

This is a retrospective, relational-analytic and qualitative study, based on Grounded Theory(12). This method is useful to explore new study fields or research objects, of which there is limited knowledge available and, thus, is appropriate to the interest of approaching the theme of this research, that is, describing how the explanations that nurses give of their mobbing experiences are related to coping strategies, with the influence of personal and contextual factors, considering that in Chile mobbing is a relatively new theme and there is no evidence about nurses available.

The participants were selected respecting the pertinence, adequacy, convenience, opportunity and availability criteria for data collection. Using convenience and snow ball sampling, thirteen nurses were contacted to participate in the study, and were interviewed between January and May 2007. All were Chilean and identified themselves as victims of mobbing while in their professional role (excluding physical violence, sexual harassment and any kind of violence performed by users of the health system). Data were collected through semi-structured interviews with a thematic guide validated and developed from guiding questions based on the available evidence. All of them were recorded, transcribed and fully analyzed, beginning the codification process. After this first codification, a second interview was performed and, following the same procedure as before, it was codified. In light of these codifications, modifications were made to the interview guide to deepen some themes, a procedure which was repeated with the analysis of the following interviews. The criteria to end the interview was theoretical saturation(12). The organization and analysis was done manually according to the procedures of Grounded Theory. Open codification was used to identify the emerging concepts, their properties and dimensions. For the relational analytic analysis, two axial codifications were carried out in related categories and subcategories into agglutinating axis and one selective codification to integrate the main categories into a wider theoretical scheme that permitted formulating an explicative model(12).

To decrease researcher's bias, the relevant categories were determined according to the results brought by the interviews, the bibliographical background and triangulation by experts.

The confidentiality of information, the autonomy of the participants and the protection of their dignity was assured by getting free and informed consent, approved for the Research Project $n^{\circ} 0702005010$ (Purdue University Institutional Review Board).

\section{Results}

The participants, at the time they were victims of mobbing, were aged between 23 and 56 years. Most were single, worked in public and private services, outpatient clinics and hospitals. The average performance on the job was 3.9 years (from 6 months to 14 years) and the average duration of harassment was 19 months ( 2 to 84 months). Among the harassers, 11 were nurses, of which 9 worked as chief nurses.

The codes obtained in the open codification were grouped around two aspects that are highlighted in the descriptive results (axial codification). The second stage (selective codification) enabled building a comprehensive model that articulated the essential aspects of the results, surrounding the studied phenomenon. 
The relational analysis indicated that the organizational context, clarity in the performance of the nurse role, the characteristics of the harassment acts and the factors involved in their coping mechanisms act as facilitators in the occurrence of mobbing in this group.

Regarding the organizational context, the characteristics of the work environment, the incentive system, the institution's conflict resolution policy and the actions of the chiefs (not directly related to the victim), directly affect the occurrence and maintenance of mobbing, and the latter two are identified as influencing elements, by themselves, in the course of the conflict. Thus, clear policies as to the manner and time in which a conflict should be solved and the behavior nursing chiefs have toward the accusation, mark the difference in the perceived support and in the coping of the victim with the events.

At some point I said "she will stand by my side"... I had the feeling she would always support me, but it was not like that, this, I believe, was the hardest moment and when I felt she took to my heels, closed the door to me and someone unknown beat me... (Nurse 10).

Another factor identified refers to the clarity of the nurses in performing their professional role, which would be influenced by technical university training (with little development of a critical thought, able to distinguish and highlight the focus of the subject) and, on the other hand, the social image attributed to the nurse, which would be influenced by the cultural legacy that place them in a role coming from the religious care, supervised by the physician and by the expectations people have of them, according to their level of specialization and the socioeconomic level of the population who judge them.

Nurses are always afraid of showing what they know and what they can do.... the lack of safety....physicians keep being something like a God, then you cannot make a comment that is different than what the physician thinks... (Nurse 8).

According to the coordination of these elements, the professional role of nurses is performed following different standards that are able to deal with the concrete reality of building the role and the paradigms that they recognize as theirs and that distinguish the profession.

They also distinguish personal characteristics that influence the execution of the role and the occupational relationship styles: it is possible to differentiate those that highlight subordination or authoritarianism and the two patterns to develop the work, the first establishing horizontal teamwork relationships with closeness and the second one that highlights the vertical feature of the relationships, keeping them apart from their partners.

In this kind of work relationship, hostile actions are characterized as being hidden, reiterated, persistent over time and comprising the personal and professional aspects of the victim, being the object of intimidating and threatening actions, mostly related to verbal insults and rumors about their personal life. In the professional area, the actions try to make the performance and development of work difficult, hide relevant information and threaten the professional status of the victim.

It was as if you felt that they were talking about you, that they are trying to cause you harm, but you do not see anybody... (Nurse 5).

Due to the ceaselessness and reiteration over time of the attacks, the victims use coping strategies that try to end with harassment by confronting or revealing it (active), or decreasing the contacts with the harasser and abandoning the conduct (passive). It is observed that many times they change from active to passive and vice versa, due to the unfruitful results of the first trials of resolution.

I would say that I kept silent and tried to go through avoidance, that is, almost annulling myself and getting out of the way... (Nurse 12)

These strategies, however, can be changed and/or reinforced, according to the definition that nurses give to the experience, the motivations to keep working and the reaction of the witnesses.

Considering all the described components, a comprehensive model was established articulating the historical, contextual and personal variables to explain the phenomenon (Figure 1) 


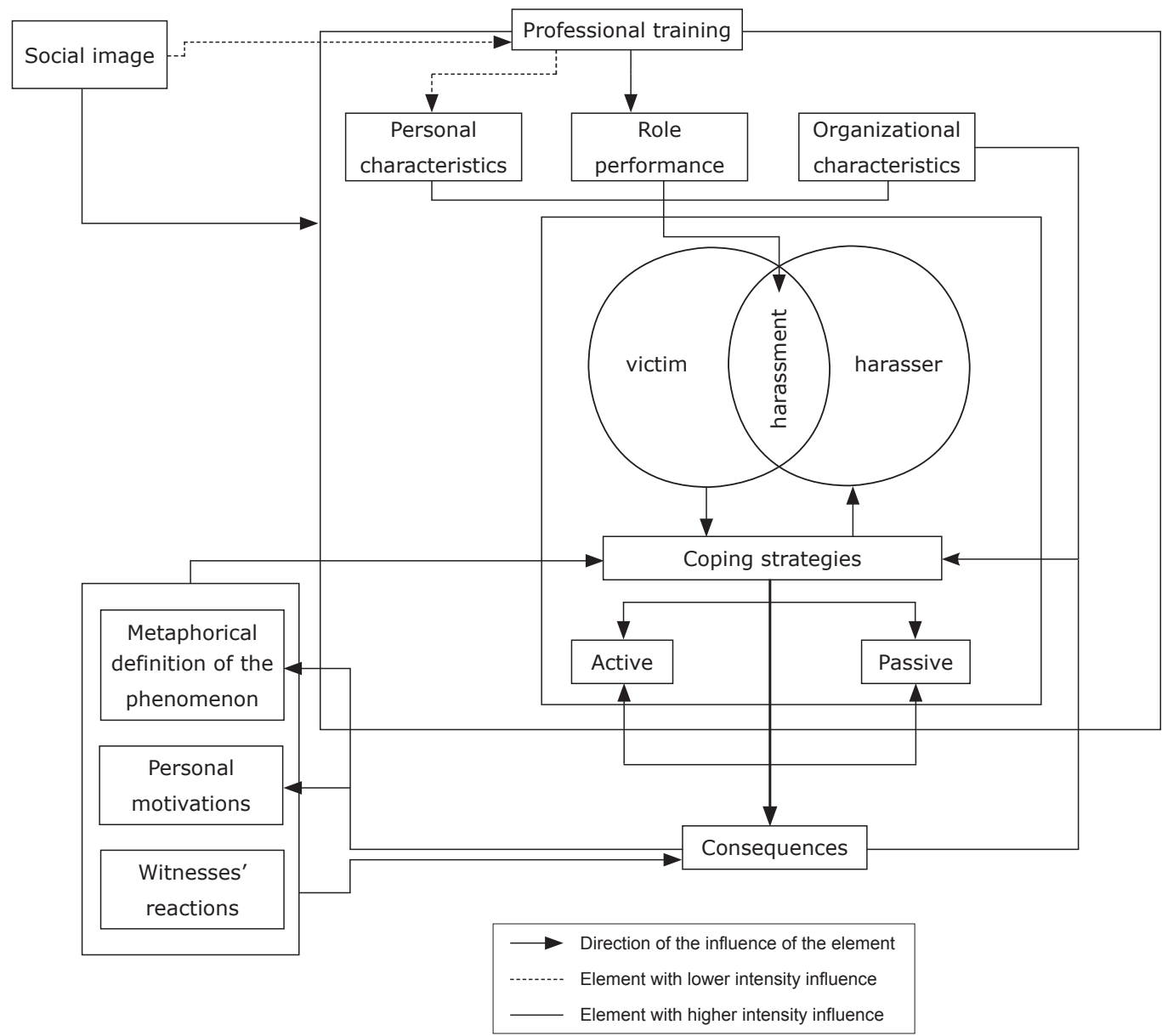

Figure 1 - Explicative model of nursing occupational hostility

In this context, there are historical factors related to the development of the profession and mediated by gender socialization, received by nurses as women, who play an essential role in the construction of their social image and in the characteristics of the professional training received, and that determines the way in which nurses will develop and perform their professional roles.

Concerning social image, it is highlighted that it is also possible to identify elements related to religious legacy - determinant in the development of nursing in Latin America during the Spanish conquest, due to which the professional role is associated with modesty and someone who serves - and also elements related to a technical role subordinated to the medical practice that characterizes the reformism era(13). The great scientific/ disciplinary development of the profession in the last fifty years could not overcome the cultural barrier that permeates the collective imagination and that, according to nurses themselves, place them primarily in a role of non professional service, which would be, partially, reinforced by excessively technical university training.
Moreover, when analyzing the social image of the nurse, it is not possible to conclude that, as they are mostly women, they also answer to the characteristics associated to the female role in society. Service and care have been historically seen within the limits of the family domain, and its extension to care for others is still seen as a prolongation of the domestic role, which determines the social position of the women and consequently of nurses ${ }^{(14)}$, characterizing those who assume this duty as sensible, generous, passive, obedient and dependent ${ }^{(15)}$, elements that are recognized by nurses as part of their social image and from which is impossible to deny the mandate of being permanently nice.

The training received would be, in this reasoning, determinant in the formulation of their social role, thus establishing a perpetrating and reinforcing cycle. Nurses report that it is precisely professional training that plays a fundamental role in the occurrence of mobbing, as it is highly influenced by the overvaluation of technique and the difficulty in developing attitudes that would permit them to have a professional position in performing 
their role, that is, in a role actively and autonomously performed, as from the critical reflection of nursing situations, as opposed to what other researchers propose ${ }^{(16)}$.

Social image and training, however, are not isolated conditions; they directly influence who is in the training process. Participants describe that, many times, students are victims of harassment, which could contribute to incorporating a violent relationship pattern as a common way to develop work, making the phenomenon seem invisible, as if it was a component of the profession(5). This is corroborated by the available evidence and also a situation that conflicts with some proposals offered by researchers $^{(16)}$. Nurses also consider it relevant that the occurrence and maintenance of mobbing is related to the characteristics of the place of work. In general, the health services tend to reproduce culturally legitimated power models in their functioning that reinforce the asymmetric roles present in such institutions. In the case of mobbing, it would occur in organizations in which the predominate systems of belief and value validate authoritarianism as a form of relation and, furthermore, perpetuate hierarchical relations considered immovable ${ }^{(17)}$. These are elements that are described by the nurses while analyzing the influence of the institutional context, where they work, and that facilitate the occurrence of mobbing in this group. In addition, all of them worked in large-sized institutions, which did not have clear conflict resolution and incentive policies, making the maintenance and permanence of mobbing easier ${ }^{(1,18-}$ 19), which are also work environments with high stress and workload levels, with an impersonal, cold and poor atmosphere, that facilitate the occurrence of harassment and have also been reported as an intervening element by other authors ${ }^{(18)}$.

Lastly, another institutional factor highlighted is the role of the chief nurses, who are not directly involved in the mobbing, but who change the course of the events depending on the actions they take. Nevertheless, the greatest part of nurses perceived less support than they expected, which is in accordance with other studies, a situation that is relevant due to the impact it has in the mental health of the nurses and in the choice of the coping strategies they use ${ }^{(5,8)}$.

These contextual characteristics structure the framework on which mobbing is founded. As in other studies, it mainly considered nurses in two positions (victim and harasser) ${ }^{(5,8)}$, who changed their habitual relationship pattern to start a harassment cycle $^{(1)}$, which, most of the time, ended with resignation from the institution, without penalty to the harassers or institutional amends to the victims.

Among the most frequent practices in this group are verbal harassment and hiding information relevant to work, as well as behaviors that attack the public image and the professional status of the victim, spreading rumors, criticizing work performance, assigning duties below their capacity or making their accomplishment more difficult, which is in accordance with the findings by other researchers ${ }^{(1,7)}$. The harassing behaviors cause a subjectively stressful experience for the victims, which activates different coping strategies, and the success or failure of which, or of the control of the situation, can determine much of the meaning and duration of the consequences.

There was evidence that, such as in the literature, nurses themselves set a deadline to solve the situation and changed from a passive to an active strategy once the deadline was past, or even made more explicit trials aiming to stop the evolution of the actions. It was also found that nurses who first replied actively to the violent behavior, drained their defensive strategies, especially if they did not find explicit support from the organization or if the consequences of the actions were perceived as severe, which made them use more passive coping strategies.

Nevertheless, besides the consequences themselves, or due to the duration of the harassment, interviews indicated three specific elements that influenced the coping strategies used directly. The first is related to the reason to remain at work, which was associated with work security and affective bonding developed during the work at the institution. If these were sufficiently strong enough to function as a restraint, they contributed to decrease the consequences of harassment. On the other hand, it is also highlighted that the psychological deterioration of the nurses makes them undervalue their professional competence, which motivated them to make an effort in maintaining their jobs, believing that this would be the only work source they would have.

The third factor is related to the metaphorical definition given to the phenomenon, which explains the quality of the experience they had, enabling the rescue of the meanings that the experience had to them, as well as making explicit the processes they imply and the results they produce. These narratives could help to reveal how the situation came to be, as alternative images of what happened and a more compatible way to manage the conflict in a constructive way, once, somehow, the representations of the violence incorporate the meaning 
given to the experience ${ }^{(20)}$. When the metaphors used included elements of direct resolution, the initial coping strategies were more active (confrontation and explicit request for help).

Then you have to walk like you do in the jungle, looking everywhere, because you know that the daggers can come from anywhere (Nurse 13).

On the other hand, if the metaphor incorporated catastrophic elements, the strategies were more passive.

I was falling into a hole and I had nowhere to hold myself, I was falling and falling (Nurse 7)

In both cases this can be associated with narrative representations that are dynamic, structuring and perseverating constructions that take into account cognitive and emotional processes that produce meaning and that constitute schemes that organize reality ${ }^{(20)}$.

\section{Discussion}

From the previously exposed information, it is possible to relate the elements that nurses identify as part of their mobbing experience with the understanding of violence according to the Ecological Model. Centering attention on the macro system, it is possible to distinguish some elements that consist of particular features of nursing's sociocultural reality, associated with the culture of the health organizations, the historical development of the profession, the influence of the gender inequalities and the social imagery that has been constructed around nurses, that could be acting as a basis that sustains the abusive relationships they suffer at work, and that would be recreated in the health institutions that form part of the victim's ecosystem. These relationships would tend to reproduce socially accepted functioning models that reinforce the asymmetry of roles regarding power and that, on the other hand, are centered on accomplishing goals and targets, making people seem invisible and creating contexts favorable to the occurrence and maintenance, without punishment, of the harassment practices.

In the micro and meso systems, nurses have relationships in the work environment that are described as hierarchical, rigid, intolerant of conflict and that legitimate abusive behaviors as a common form of relationship.

Lastly, under the individual perspective, the way nurses establish their work relationship and build explanations for harassment, are related to the personal dimensions proposed in the literature. The way nurses regard their experiences, the relationship and communication patterns with other people and the level of self esteem and/or emotional weakness were described with particular characteristics, both for victims and harassers, in a relationship that, to those involved, is directly associated to the occurrence and maintenance of mobbing.

\section{Final considerations}

Mobbing with nurses is a circular phenomenon that causes high levels of stress in those who experience it. In the cases of nurses, besides reverberating in different areas of their life and health, it also affects, as secondary victims, the users who receive care from them. The elements that intervene in the development and maintenance of mobbing are recursively related, and it is possible to distinguish a concatenation of factors that explains the complexity of the phenomenon itself and that are related to training, historical and cultural aspects, considering among them the organizational culture of the health institutions, as well as some characteristics of the involved actors and of the work relationship style, that would propitiate an endless cycle of harassment, in which actions perpetrated against the victims and their coping strategies would mutually influence one another, being related to the narrative constructions of the phenomenon and to contextual elements, all possibly being considered as part of the greater frequency of occurrence and its evolution.

As nurses, it is not possible to abstain from this reality. There should be an assumption of an active role in the prevention of its occurrence and intervention in the case of those factors that can be modified. The need to widen and deepen the study of work harassment in nursing is evident, aiming to understand the characteristics of this phenomenon in the Chilean context and also, in the same way, it is relevant to have further research on the characteristics of university training and the model students receive, which could be related to the process of constructing a professional identity and the maintenance of cultural values associated with gender and the use of power.

In the work area, there is a need to research the aspects that contribute to making violence invisible in the nursing teams, so that work harassment is considered a problem that goes against the ethical principle of respect for others and is defined as an unacceptable situation in the relationships established inside the work teams, regardless of the hierarchy and situation of the people involved, or the specific characteristics of work contexts. 
It is not possible to manage care for others if nurses do not practice self-care, and if they do not consider themselves worthy of being taken care of. Thus, preventive work is a moral imperative that cannot be disregarded.

\section{Acknowledgment}

To María Paz Tagle, PhD, who guided the development of this research.

\section{References}

1. Topa G, Depolo M, Morales JF. Acoso laboral: metaanálisis y modelo integrador de sus antecedentes y consecuencias Psicothema. 2007;19(1):88-94.

2. Amnistía Internacional. El Cuidado de los Derechos humanos: Oportunidades y desafíos para el personal de enfermería y partería. Madrid (España): Amnistía Internacional; 2006.

3. Kwok R, Law Y, Li K, Ng Y, Cheung M, Fung, V, et al. Prevalence of workplace violence against nurses in Hong Kong. Hong Kong Med J. 2006;12(1):6-9.

4. Woelfle C, McCaffrey R. Nurse on Nurse. Nurs Forum. 2007;42(3):123-31.

5. Royal College of Nursing. 2002. Working well: a call to employers. [acesso em: 5 dezembro 2007]. Disponível em:http://www.rcn.org.uk/members/downloads/ working_well_summary.pdf

6. Eriksen W, Einarsen S. Gender minority as a risk factor of exposure to bullying at work: The case of male assistant nurses. Eur J Work Organ Psicol.. 2004;13(4):473-92.

7. Atawneh F, Zahid M, Al-Sahlawi K, Shahid A, Al-Farrah $M$. Violence against nurses in hospitals: Prevalence and effects. Br J. Nurs. 2003;12:102-7.

8. Quine L. Workplace bullying in NHS community trust: Staff questionnaire survey. BMJ. 1999; 18:228-32.

9. Yildirim D, Yildirim A, Timucin A. Mobbing Behaviors Encountered by Nurse Teaching Staff. Nurs Ethics. 2007;14(4):447-63.

10. Trindade LL, Lautert L, Beck, CLC. Mecanismos utilizados para enfrentar el agotamiento por trabajadores que actúan en el programa Estrategia de la Salud de la Familia Rev. Latino-Am. Enfermagem [internet]. 2009 [acessado em 15 junho 2010]; 17(5):607-12. Disponível em: http://www.eerp.usp.br/rlae

11. Juárez-García A, Hernández-Mendoza E, RamírezPáez JA. Mobbing un riesgo psicosocial latente en el trabajo de enfermería. Revista de Enfermería del Instituto Mexicano del Seguro Social [internet]. 2005 [acesso em
10 dezembro 2007]; 13(3): 153-60. Disponível em: http://www.medigraphic.com/pdfs/enfermeriaimss/ eim-2005/eim053f.pdf

12. Dantas CC, Leite JL, Lima SBS, Stipp MAC. Teoría fundamentada en los datos - aspectos conceptuales y operacionales: metodología posible de ser aplicada en la investigación en enfermería. Rev. Latino-Am. Enfermagem [internet]. 2009 [acessado em 15 junho 2010]; 17(4):573-9. Disponível em: http://www. scielo.br/scielo.php?script=sci_arttext\&pid=S0104$11692009000400021 \&$ lng $=$ pt.

13. Hernández J. Historia de la Enfermería: Un análisis histórico de los cuidados de Enfermería. Madrid: Mc Graw Hill; 1995. 150 p.

14. García A, Sainz A, Botella M. La enfermería vista desde el género. Index Enferm. 2004;13(46):45-8.

15. Fajardo $M E$, Germán C. Influencia del género en el reconocimiento de los cuidados enfermeros visibles e invisibles. Index Enferm. 2004;13(46):09-12.

16. Rodrigues ZM, Gomes EL. Background and managerial practice of nurses: paths for transforming praxis. Rev. Latino-Am. Enfermagem [internet]. 2008 [acessado em 8 novembro 2008]; 16(1):71-7. Disponíve em: $\quad$ http://www.scielo.br/scielo.php?script=sci_ arttext\&pid=S0104-11692008000100012\&lng=es\&nrm =iso\&tlng $=$ es

17. Ravazzola MC. Historias infames: el maltrato en las relaciones. Buenos Aires: Paidos; 1998. 288 p.

18. Moreno B, Rodríguez A, Garrosa E, Morante ME. Antecedentes organizacionales del acoso psicológico en el trabajo: Un estudio exploratorio. Psicothema. 2005;17(4):627-32.

19. Salin D. Ways of explaining workplace bullying: A review of enabling, motivating and precipitating structures and processes in the work environment. Human Relations. 2003;56(10):1213-32.

20. Rodrigo M. La narrativización de la violencia. Quaderns del CAC. 2003;17:15-21. 